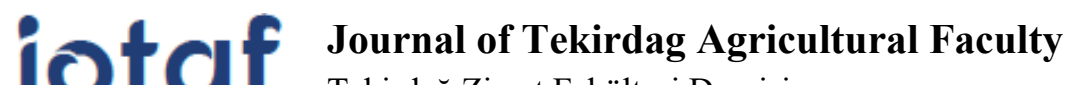

Tekirdağ Ziraat Fakültesi Dergisi

\section{Maş Fasulyesi Tohum Hasadı Artıklarının Hayvan Beslemede Kullanılabilme Potansiyeli}

Potential of Mung Bean Seed Harvest Residues in Animal Nutrition

\section{Ruziye KARAMAN ${ }^{1}$, Cengiz TÜRKAY ${ }^{2}$, Muharrem KAYA ${ }^{3}$}

\section{$\ddot{\mathbf{O} z}$}

Anavatanı Hindistan olan maş fasulyesi türü, uzun yıllardan beri ülkemizde insan beslenmesinde kullanmak amacıyla yetiştirilmektedir. Bu araştırmada ülkemizde yetiştiriciliği yapılan maş fasulyesi yerel genotiplerinin ve yurt dışından temin edilen tescilli çeşitlerin tohum hasadı yapıldıktan sonra kalan kısımlarının yem olarak kullanılabilme potansiyelinin belirlenmesi amaçlanmıştır. Çalışma, Isparta Uygulamalı Bilimler Üniversitesi Ziraat Fakültesi deneme arazilerinde 2019 yılında, tesadüf blokları deneme deseninde faktöriyel düzenlemede üç tekerrürlü olarak kurulmuştur. Çalışmada, 18 maş fasulyesi genotipi ve 4 adet tescilli çeşit (Jade-AU, Vidiyala, Partow ve Kalkınısh) kullanılmıştır. Bitki kısımları olarak, tohum hasadından sonra kalan gövde, yaprak ve bakla kabukları kullanılmıştır. Çalışmada asit deterjanlarda çözünen lif içeriği (ADF), nötr deterjanlarda çözünen lif içeriği (NDF), asit deterjanlarda çözünen lignin içeriği (ADL), selüloz, toplam sindirilebilir besin maddesi (TSBM), nisbi yem değeri (NYD) ve metabolik enerji (ME) parametreleri incelenmiştir. Elde edilen bulgulara göre genotiplerde NDF içeriği \% 37.72-46.92, ADF içeriği \% 24.40-34.11, ADL içeriği \% 6.19-9.93, TSBM \% 57.30 - 69.84, selüloz içeriği \% 15.92-24.17, NYD 142.07-193.46 ve ME 8.61- $9.89 \mathrm{MJ} \mathrm{kg}^{-1}$ arasında değişmiştir. ADF, NDF, ADL ve selüloz içeriği bakla kabuklarında yüksek değerlere sahip olsa da, yem değerlerine ait sınıflandırmalar bakımından belirlenen değerler gövde kısmında tespit edilmiştir. TSBM, NBY ve ME özelliklerinde yaprak kısmı yüksek değerlere sahip olmuştur. Sonuç olarak en iyi yem değerleri bitki artıklarının gövde kısmında belirlenmiş olup, maş fasulyesi genotip ve çeşitler arasında 21 B 01 ile 27 S 08 genotiplerinde tespit edilmiştir. Elde edilen sonuçlar doğrultusunda maş fasulyesi genotiplerinin hayvan beslemede potansiyel bir yem olabileceği düşünülmektedir.

Anahtar Kelimeler: Maş fasulyesi, Yaprak, Bakla kabuğu, Yem değeri, Kalite, Hayvan besleme

\footnotetext{
*Sorumlu Yazar/Corresponding Author: Ruziye KARAMAN, Isparta Uygulamalı Bilimler Üniversitesi Ziraat Fakültesi Tarla Bitkileri Bölümü, Isparta. Türkiye. E-mail: ruziyekaraman@isparta.edu.tr. (D) OrcID: 0000-0001-5088-8253

${ }^{2}$ Cengiz TÜRKAY, Isparta Uygulamalı Bilimler Üniversitesi Ziraat Fakültesi Tarla Bitkileri Bölümü, Isparta. Türkiye. E-mail: cengiz3370turkay@gmail.com OrcID: 0000-0003-3857-0140

${ }^{3}$ Muharrem KAYA, Isparta Uygulamalı Bilimler Üniversitesi Ziraat Fakültesi Tarla Bitkileri Bölümü, Isparta. Türkiye. E-mail: muharremkaya@isparta.edu.tr OrcID: 0000-0001-6973-9178

Atıf/Citation: Karaman, R., Türkay, C., Kaya, M. (2021). Maş Fasulyesi Tohum Hasadı Artıklarının Hayvan Beslemede Kullanılabilme Potansiyeli. Tekirda $\breve{g}$ Ziraat Fakültesi Dergisi, 19 (1), 108-119.

CBu çalışma Tekirdağ Namık Kemal Üniversitesi tarafından Creative Commons Lisansı (https://creativecommons.org/licenses/by-nc/4.0/) kapsamında yayınlanmıştır. Tekirdağ 2022
} 


\begin{abstract}
Mung bean species, whose origin is India, has been grown to use in human nutrition for many years in our country. The aim of this study, was determined to use as potential forage after genotypes, cultivated in Turkey, and varieties, obtained from foreign, harvest the residue. 18 genotypes and 4 registered mung bean varieties ((Jade-AU, Vidiyala, Partow ve Kalkınısh) were used as seed material in the study.The study was carried out at the Isparta University of Applied Sciences, Faculty of Agriculture experiment fields according to completely random plot trial design in factorial arrangement with three replications in 2019. The stems, leaves and pod wall remaining after the seed harvest were used as plant parts. It was examined asit detergent fiber content (ADF), nötr detergent fiber content (NDF), asit detergent lignin content (ADL), cellulose, total digestible nutrition (TDN), relative feed value (RFV) and metabolic energy (ME) parameters. According to obtained the data were varied between ADF content 24.40 34.11\%, NDF content 37.72 - 46.92\%, ADL content 6.19 - 9.93\%, TDN content 57.30 - 69.84\%, cellulose content 15.92 - 24.17\%, RFV 142.07 - 193.46 and ME 8.61 - 9.89 $\mathrm{MJ} \mathrm{kg}^{-1}$. Although the ADF, NDF, ADL and cellulose content in the plant parts has high values in pod husk but, the desired values in terms of feed value were determined in stem part. Leaves were had high value in point of TDN, RFV and ME. As a result, the best forage values were determined in the stem part of the plant residues, and among the mung bean genotypes and cultivars, $21 \mathrm{~B} 01$ and $27 \mathrm{~S} 08$ genotypes were determined. According to the results obtained, mung bean genotypes are thought to be a potential feed in animal nutrition.
\end{abstract}

Keywords: Mung bean, Leaf, Pod husk, Feed value, Quality, Animal feed 


\section{Giriş}

Ülkemizde hayvanların kaba yem kaynağını çayır-meralar ve tarım alanlarında yetiştirilen yem bitkileri oluşturmaktadır. Bunların dışında bitkisel üretimde hasattan sonra kalan sap ve saman artıkları da rasyonlarda kaba yem kaynağı olarak kullanılmaktadır. Özellikle sahil kuşaklarında kaba yem kaynağı olarak bitki artıkları; iç kesimlerde ise hububat artıkları fazlaca kullanılmaktadır (Gökkuş, 2011). Ülkemizde toplam 14.6 milyon ha çayırmera alanı ve 1.96 milyon ha yem bitkileri ekim alanı bulunmaktadır (Anonim, 2018). Ülkemizde bulunan yaklaşık 19 milyon büyükbaş hayvan birimine eşdeğer hayvan için ihtiyaç duyulan 86.9 milyon ton/yıl düzeyindeki kaliteli kaba yeme ihtiyacının sadece \%35.7' lik kısmı karşılanabilmektedir (Acar ve ark., 2020). Bato ve ark. (2021), meralardan elde edilen kaba yemlerin hayvan beslemede yeterli miktarda olmadığını bildirmişlerdir. Ayrıca, araştırmacılar, verim ve kalite bakımından yüksek değerlere sahip, her bölgeye adapte olabilecek farklı kaba yem bitkilerine ihtiyaç olduğunu ifade etmişlerdir. Bu bağlamda kaba yem açığının kapatılması için, alternatif bir kaba yem kaynağı olarak maş fasulyesinin hasat artıkları hayvan beslemede önem arz edeceği düşünülmektir.

Anavatanı Hindistan olan maş fasulyesinin, özellikle Asya, Güney Avrupa ve Güney ABD’de yaygın olarak yetiştirilmektedir. Ülkemizde ise Akdeniz ve Güneydoğu Anadolu bölgelerinde yaklaşık 200 yıldır lokal olarak yetiştiriciliği yapılmaktadır. Maş fasulyesi yılda iki kez, (ilkbahar ve sonbaharda) kısa sürede (60-90 gün) yetiştirilebilen ve diğer yazlık ürünlere göre daha az su ihtiyacı olan bir baklagil türüdür (Anjum ve ark., 2006; ElSalam ve ark., 2013). Monokültür tarım yapıldığı, protein kaynaklarının sınırlı ve ulaşımının güç olduğu yerlerde maş fasulyesi hem üreticilere hem de tüketicilere fayda sağlamaktadır (Benlioğlu ve Özkan, 2020). Maş fasulyesi tanelerinin insan ve hayvan beslenmesinde kullanılmasının yanında, bitki kısımları yeşil gübre, yer örtücü, kaba ve konsantre yem (taneleri) olarak kullanılabilmektedir. Maş fasulyesinin, İskenderiye üçgülü ve yonca gibi besleyici bir yem değerine sahip olduğu, hayvanlar tarafindan sevilen ve son derece lezzetli bir baklagil türü olduğu vurgulanmaktadır (Boe ve ark., 1991; Ullah ve ark., 2012). Yemlik olarak değerlendirilebilen maş fasulyesi, ham protein içeriği bakımından zengin olup, kuru madde esasına göre yaklaşık \%16-18 protein içermektedir (Abd ElSalam ve El-Habbasha, 2008). Maş fasulyesi çeşitlerinin yem değerleri bakımından genellikle ham protein, kül ve TSBM içeriği özellikleri yönünden yüksek iken, mısır ile karşılaştırıldığında ham selüloz ve serbest azot içeriği düşüktür (El-Salam ve ark., 2013). Bunun yanında maş fasulyesinin genotiplere, uygulamalara ve yetiştirme koşullarına göre değişmekle beraber, tane verimi 35-225 kg da (Çancı ve Toker, 2005); kuru ot verimi ise 0.641.8 ton $\mathrm{ha}^{-1}$ arasında değişim göstermektedir. Uslu ve ark. (2020), yemlik bezelye ve yemlik bakla bitki kısımlarının (tüm bitki, yaprak, sap ve dal) kalite özelliklerini inceledikleri çalışmada en yüksek ham kül, kuru madde ve ham protein içeriklerini yaprak kısmında belirlemişlerdir. Ayrıca, tüm bitki, sap ve dal kısımlarının yaprak kısmına göre besin elementi bakımından daha fakir ve besleyiciliği daha düşük olduğunu ifade etmişlerdir.

Vigna mungo türünün bakla kabuğunda \%9.0 ham protein, \%2.3 yağ, \%29.9 ham selüloz ve \%12.2 ham kül içerirken, tohum kabuğunda \%18.2 ham protein, \%1.4 yağ, \%20.3 ham selüloz, \%48.2 NDF, \%37.4 ADF, \%10.8 hemiselüloz, \%26.6 selüloz ve \%9.6 lignin içermektedir (Sherasia ve ark., 2017). Islam ve ark. (1997), Bangladeş'te, maş fasulyesi kabuklarının değerli bir yem olduğunu bildirmişlerdir. Ayrıca aynı araştırıcılar bu kabukları tüketen hayvanlarda daha fazla protein alımına bağlı olarak daha yüksek canlı ağırlık artışı (sadece otla beslenen keçilerde 31-51 g gün ${ }^{-1}$ ) saptamışlardır. Venkateswarlu ve ark. (2013), buffalo beslenmesinde rasyona ilave ettikleri siyah maş fasulyesi samanının NDF içeriğini \%72.56, ADF içeriğini \%66.69, ADL içeriğini \%13.36, hemiselüloz içeriğini \%5.87 ve selüloz içeriğini \%54.6 olarak belirlemişlerdir.

Abd El-Salam ve ark. (2008), maş fasulyesi samanının kuru madde, organik madde, ham protein, ham lif, ham yağ, serbest azot içeriği ve ham kül içeriğini sırasıyla \%88.20, \%88.57, \%9.70, \%26.57, \%2.39, \%49.91 ve \%11.43 olarak belirlemişlerdir. Omer ve ark. (2018), maş fasulyesi, kuru fasulye ve fistık samanlarının ve yan ürünlerinin tavşanların beslenmesinde önemli yer aldığını bildirmişlerdir. Yapılan literatür çalışmalarında bitkilerin kök, gövde, yaprak ve çiçek organlarının hayvan besleme açısından sindirim değerlerinin değişiklik gösterdiği tespit edilmiştir (Van Soest, 1994; Uslu ve ark., 2020). Literatürler incelendiğinde maş fasulyesi hasat edildikten sonra samanlarının hayvan beslemede kullanıldığı bildirilmektedir. Ancak maş fasulyesi sap/samanının yem değeri parametreleri hakkında çok fazla bilgi bulunmamaktadır. Bu nedenle çalışmada, Türkiye'de yetiştiriciliği yapılan maş fasulyesi genotiplerin ve farklı ülkelerden temin edilen tescilli çeşitlerin tohum hasadı yapıldıktan sonra kalan bitki kısımlarının yem olarak kullanılabilme potansiyelinin belirlenmesi amaçlanmıştır. 


\section{Materyal ve Yöntem}

Denemede materyal olarak Adıyaman (02 G 05), Antalya (07 A 02, 07 A 05, 07 G 01, 07 G 08 ve 07 G 09), Diyarbakır (21 B 01), Gaziantep (27 S 01 ve 27 S 08), Mersin (33 M 02), Kahramanmaraş (46 G 01), Nevşehir (50 N 01), Tokat (60 M 01), Van (65 M 01), Şırnak ( 73 A ve 73 C) ve Kilis ( 79 M 01 ve 79 M 02) illerinden temin edilen yerel maş fasulyesi genotipleri ile yurtdışında tescilli 4 çeşit [Jade AU (Avustralya), Partow (İran), Vidiyala (Irak) ve Kalkınısh (Türkmenistan)] bitki materyali olarak kullanılmıştır. Her bir genotip ve çeşitlerin hasattan arta kalan kısımları (gövde, yaprak ve bakla kabukları) çalışmanın diğer bir faktörünü oluşturmaktadır.

Çalışma 2019 yılında Isparta ekolojik koşullarında, tesadüf blokları deneme deseninde faktöriyel düzene göre 3 tekerrürlü olarak yürütülmüştür. Denemede her bir parsel, $6 \mathrm{~m}$ uzunluğunda ve 6 sıradan oluşmuştur. Ekim normu, sıra arası ve üzeri 30x10 cm olacak şekilde ayarlanmıştır. Ekim işlemi 30 Nisan tarihinde el ile yapılmıştır. Ekim sırasında her parsele $3 \mathrm{~kg} \mathrm{da}^{-1} \mathrm{~N}$ ve $6 \mathrm{~kg} \mathrm{da}^{-1} \mathrm{P}_{2} \mathrm{O}_{5}$ olacak şekilde gübreleme yapılmıştır (Meral ve ark., 1998). Deneme parselleri çıkıştan itibaren 1'er hafta aralıklarla gerektiği oranda damla sulama yöntemiyle sulanmıştır. Yabancı otlara karşı mücadele gerektiğinde elle ve çapalama yöntemi şeklinde yapılmıştır. Parselden rastgele seçilen 20 bitkinin tane hasadı yapılıp geri kalan bitki kısımları gövde (yaprak+sap: bitkinin hasat edilip, baklaları alındıktan sonra kalan kısmı), yaprak ve bakla kabukları olarak ayrılmışlardır. Ayrılan bitki kısımları $65^{\circ} \mathrm{C}$ 'de sabit ağırlığa gelene kadar etüvde kurutulmuşlardır. Kurutulan bitki kısımları kimyasal analizlerde kullanılmak için öğ̈̈tülmüştür.

Örneklerin; NDF, ADF ve ADL içerikleri, Van Soest ve ark. (1991), tarafından bildirilen yöntemlere göre ANKOM 200 Fiber Analyzer (ANKOM Technology Corp., Fairport, NY, USA) cihazı kullanılarak analiz edilmiş̧tir. Anonymous (2006), göre selüloz (\%) içeriği hesaplanmıştır (Eş.1).

Selüloz İçeriği: ADF-ADL

Nispi yem değeri (NYD)'nin belirlenmesinde Van Dyke ve Anderson (2000), tarafindan geliştirilen eşitlikler 2 ve 3' den faydalanılmıştır (SKM: Sindirilebilir kuru madde; KMT: Kuru madde tüketimi).

$$
\begin{aligned}
& \text { NYD }(\%)=\% \text { SKM } \times \text { \%KMT x } 0.775 \\
& \text { SKM }(\%)=88.9-(0.779 \times \% \text { ADF }) ; \% \text { KMT }=120 / \% \text { NDF }
\end{aligned}
$$

Toplam sindirilebilir besin maddesi (TSBM) ve metabolik enerji (ME) içerikleri Moore ve Undersander (2002), tarafından geliştirilen eşitlik 4 ve 5 yardımıyla hesaplanmıştır.

$\operatorname{TSBM}(\%)=82.38-(0.7515 \times \%$ ADF $)$

$\operatorname{ME}\left(\mathrm{MJ} \mathrm{kg}^{-1}\right)=0.17 \times$ \% SKM -2.0

Çalışmanın yapıldığı yılda, ortalama sıcaklık $\left(19.1^{\circ} \mathrm{C}\right)$ uzun yıllar ortalamasının $\left(17.8^{\circ} \mathrm{C}\right)$ üzerinde, ortalama nispi nem (\%54.5) aynı döneme ait uzun yıllar ortalamasından (\%54.3) daha yüksek olmuştur. Toplam yıllık yağış miktarının ise $(196.6 \mathrm{~mm})$ aynı döneme ait uzun yıllar toplam yağış miktarından $(231.3 \mathrm{~mm})$ daha az olduğu belirlenmiştir. Deneme alanında yapılan toprak örneklemelerine göre; deneme topraklarının killi-tınlı yapıda, hafif alkali (pH değeri 7.7), hafif tuzlu, kireçli, organik madde içeriği bakımından fakir (\%1.5), fosfor bakımından yeterli $\left(23.5 \mathrm{mg} \mathrm{kg}^{-1}\right)$ seviyede, potasyum bakımından zengin $\left(772.2 \mathrm{mg} \mathrm{kg}^{-1}\right)$ olduğu belirlenmiştir.

Araştırmadan elde edilen verilerin istatistiksel değerlendirilmesinde tesadüf blokları deneme deseninde faktöriyel deneme düzenine göre TOTEMSTAT istatistik paket programından yararlanılarak varyans analizine tabi tutulmuştur. Ortalamalar arasındaki farklılıklar Duncan testi ile belirlenmiştir.

\section{Araştırma Bulguları ve Tartış̧a}

Araştırmada, maş fasulyesi çeşit ve genotiplerinin gövde, yaprak ve bakla kabuk kısımlarının; NDF, ADF, ADL, selüloz içerikleri, TSBM, NYD ve ME özelliklerine ilişkin elde edilen verilerin istatistik analizlerine göre tüm karakterlere ait genotip, bitki kısımları ve genotip $\mathrm{x}$ bitki kısımları interaksiyonları önemli $(\mathrm{P}<0.01)$ bulunmuştur. 


\subsection{NDF ve ADF içeriği}

Araştırmada genotiplerin NDF içerikleri \%37.72-46.92 arasında değişim göstermiş ve genotipler içerisinde en yüksek NDF içeriği 73 A genotipinde, en düşük ise $27 \mathrm{~S} 08$ genotipinde belirlenmiştir $(\mathrm{P}<0.01)$. Bitki kısımlarının ortalama NDF içerikleri \%27.89-58.83 arasında değişim göstermiştir. En yüksek NDF içeriği bakla kabuklarında, en düşük ise yapraklarda belirlenmiştir. NDF içeriği gövdede (yaprak + sap) en yüksek 73 A (\%49.40) genotipinde, en düşük ise $27 \mathrm{~S} 08$ (\%33.57) genotipinde tespit edilmiştir. Çeşitler ile genotipler kıyaslandığında Vidiyala çeşidi, 73 A ve 79 M 02 genotipleri ile aynı istatistiki grupta yer almıştır. Yaprakların NDF içeriği en yüksek \%38.73 ile 07 G 01 genotipinde, en düşük ise \%22.40 ile Jade-AU çeşidinde belirlenmiştir. Diğer bir bitki kısmı olan bakla kabuğunun NDF içeriği en yüksek 65 M 01 (\%62.83) genotipinde, en düşük ise 27 S 08 (\%53.80) genotipinde belirlenmiştir. Bakla kabukları için genotipler ile çeşitler kıyaslandığında Vidiyala ve Kalkınısh çeşitleri en yüksek NDF içeriklerine sahip 65 M 01, 73 A ve 46 G 01 genotipleri ile aynı istatistiki grupta yer almıştır (Tablo 1).

Tablo 1. Maş fasulyesi genotip ve çeşitlerinin bitki kısımlarına göre NDF ve ADF içerikleri

Table 1. NDF and ADF contents of mung bean genotype and varieties according to plant parts

\begin{tabular}{|c|c|c|c|c|c|c|c|c|}
\hline \multirow{2}{*}{$\begin{array}{c}\text { Genotip/ } \\
\text { Çeşit } \\
\text { Genotype/ } \\
\text { Variety }\end{array}$} & \multicolumn{4}{|c|}{$\begin{array}{l}\text { NDF İçeriği (\%) } \\
\text { NDF Content }\end{array}$} & \multicolumn{4}{|c|}{$\begin{array}{c}\text { ADF İçeriği (\%) } \\
\text { ADF Content }\end{array}$} \\
\hline & $\begin{array}{l}\text { Gövde } \\
\text { Stem }\end{array}$ & $\begin{array}{c}\text { Yaprak } \\
\text { Leaf }\end{array}$ & $\begin{array}{c}\text { Bakla } \\
\text { kabuğu } \\
\text { Pod husk }\end{array}$ & $\begin{array}{c}\text { Ort. } \\
\text { Mean }\end{array}$ & $\begin{array}{l}\text { Gövde } \\
\text { Stem }\end{array}$ & $\begin{array}{c}\text { Yaprak } \\
\text { Leaf }\end{array}$ & $\begin{array}{c}\text { Bakla } \\
\text { kabuğu } \\
\text { Pod husk }\end{array}$ & $\begin{array}{c}\text { Ort. } \\
\text { Mean }\end{array}$ \\
\hline 02 G 05 & $42.57 \mathrm{c}-\mathrm{e}$ & $29.50 \mathrm{~cd}$ & $58.93 \mathrm{c}-\mathrm{f}$ & 43.67 DE & $32.80 \mathrm{~cd}$ & $21.20 \mathrm{a}$ & 42.70 d-h & $32.23 \mathrm{BC}$ \\
\hline 07 A 02 & $44.77 \mathrm{~b}$ & $27.27 \mathrm{~d}-\mathrm{h}$ & $57.93 \mathrm{ef}$ & 43.32 DE & $33.60 \mathrm{c}$ & $14.67 \mathrm{fg}$ & $41.60 \mathrm{~g}-1$ & 29.96 E-G \\
\hline 07 A 05 & $39.37 \mathrm{f}-\mathrm{h}$ & 29.20 c-e & $60.30 \mathrm{~b}-\mathrm{e}$ & 42.96 D-F & $28.50 \mathrm{~h}-\mathrm{j}$ & $18.23 \mathrm{bc}$ & $43.17 \mathrm{c}-\mathrm{f}$ & 29.97 E-G \\
\hline 07 G 01 & $38.87 \mathrm{~g}-1$ & $38.73 \mathrm{a}$ & $60.27 \mathrm{~b}-\mathrm{e}$ & $45.96 \mathrm{~A}-\mathrm{C}$ & $29.30 \mathrm{~g}-1$ & $18.03 \mathrm{bc}$ & $43.30 \mathrm{~b}-\mathrm{f}$ & 30.21 D-G \\
\hline 07 G 08 & $43.33 \mathrm{~b}-\mathrm{d}$ & $27.83 \mathrm{c}-\mathrm{f}$ & $57.50 \mathrm{f}$ & 42.89 D-F & $33.33 \mathrm{c}$ & $15.60 \mathrm{~d}-\mathrm{f}$ & $41.53 \mathrm{~g}-1$ & 30.16 D-G \\
\hline 07 G 09 & $43.17 \mathrm{~b}-\mathrm{d}$ & $32.33 \mathrm{~b}$ & $57.50 \mathrm{f}$ & 44.33 B-D & $30.50 \mathrm{e}-\mathrm{g}$ & $21.10 \mathrm{a}$ & $41.37 \mathrm{~g}-1$ & 30.99 C-E \\
\hline 21 B 01 & $33.90 \mathrm{kl}$ & $28.13 \mathrm{c}-\mathrm{e}$ & $55.20 \mathrm{~g}$ & $39.08 \mathrm{HI}$ & $21.40 \mathrm{n}$ & $12.23 \mathrm{~h}$ & $39.57 \mathrm{j}$ & $24.40 \mathrm{~L}$ \\
\hline 27 N 01 & $37.10 \mathrm{~h}-\mathrm{j}$ & 27.00 e-h & $57.57 \mathrm{f}$ & 40.56 GH & 25.771 & $14.70 \mathrm{fg}$ & $40.17 \mathrm{ij}$ & $26.88 \mathrm{~K}$ \\
\hline $27 \mathrm{~S} 01$ & $36.50 \mathrm{ij}$ & $25.50 \mathrm{~g}-1$ & $58.40 \mathrm{~d}-\mathrm{f}$ & $40.13 \mathrm{HI}$ & $24.40 \mathrm{~lm}$ & $14.63 \mathrm{fg}$ & $41.47 \mathrm{~g}-1$ & $26.83 \mathrm{~K}$ \\
\hline 27 S 08 & 33.571 & $25.80 \mathrm{f}-\mathrm{h}$ & $53.80 \mathrm{~g}$ & 37.72 I & $23.80 \mathrm{~m}$ & $13.60 \mathrm{gh}$ & $37.97 \mathrm{k}$ & $25.12 \mathrm{~L}$ \\
\hline 33 M 02 & $42.87 \mathrm{~b}-\mathrm{d}$ & $29.00 \mathrm{c}-\mathrm{e}$ & $59.20 \mathrm{c}-\mathrm{f}$ & 43.69 CD & $32.53 \mathrm{~cd}$ & $16.90 \mathrm{c}-\mathrm{e}$ & $42.60 \mathrm{e}-\mathrm{h}$ & $30.68 \mathrm{C}-\mathrm{F}$ \\
\hline 46 G 01 & $40.40 \mathrm{e}-\mathrm{g}$ & $25.50 \mathrm{f}-1$ & $61.80 \mathrm{ab}$ & 42.57 D-G & $27.40 \mathrm{jk}$ & $17.00 \mathrm{~cd}$ & $44.10 \mathrm{~b}-\mathrm{d}$ & 29.50 E-H \\
\hline 50 N 01 & $35.80 \mathrm{j}-1$ & $24.83 \mathrm{~h} 1$ & $60.40 \mathrm{~b}-\mathrm{e}$ & 40.34 H & 25.671 & $15.50 \mathrm{ef}$ & $43.57 \mathrm{~b}-\mathrm{e}$ & 28.24 H-K \\
\hline 60 M 01 & $37.10 \mathrm{~h}-\mathrm{j}$ & $27.53 \mathrm{~d}-\mathrm{g}$ & $59.33 \mathrm{c}-\mathrm{f}$ & 41.32 E-H & $29.17 \mathrm{~g}-1$ & $15.60 \mathrm{~d}-\mathrm{f}$ & $41.83 \mathrm{f}-\mathrm{h}$ & 28.87 G-J \\
\hline 65 M 01 & $39.80 \mathrm{fg}$ & $26.90 \mathrm{e}-\mathrm{h}$ & $62.83 \mathrm{a}$ & 43.18 DE & $29.30 \mathrm{~g}-1$ & $16.80 \mathrm{c}-\mathrm{e}$ & $44.60 \mathrm{a}-\mathrm{c}$ & 30.23 D-F \\
\hline $73 \mathrm{~A}$ & $49.40 \mathrm{a}$ & $29.50 \mathrm{~cd}$ & $61.87 \mathrm{ab}$ & $46.92 \mathrm{~A}$ & $39.00 \mathrm{a}$ & $18.53 \mathrm{~b}$ & $44.80 \mathrm{ab}$ & $34.11 \mathrm{~A}$ \\
\hline $73 \mathrm{C}$ & $39.80 \mathrm{fg}$ & $29.03 \mathrm{c}-\mathrm{e}$ & $59.90 \mathrm{~b}-\mathrm{f}$ & 42.91 D-F & $28.47 \mathrm{ij}$ & $16.63 \mathrm{c}-\mathrm{e}$ & $42.93 \mathrm{~d}-\mathrm{g}$ & 29.34 F-I \\
\hline 79 М 01 & $41.50 \mathrm{c}-\mathrm{f}$ & $30.60 \mathrm{bc}$ & $60.53 \mathrm{~b}-\mathrm{d}$ & 44.21 B-D & $31.57 \mathrm{de}$ & $17.63 \mathrm{bc}$ & $43.33 \mathrm{c}-\mathrm{e}$ & 30.84 C-E \\
\hline 79 М 02 & $47.87 \mathrm{a}$ & 27.03 e-h & $58.50 \mathrm{~d}-\mathrm{f}$ & 44.47 B-D & $35.87 \mathrm{~b}$ & $17.90 \mathrm{bc}$ & $41.40 \mathrm{~h} 1$ & 31.72 B-D \\
\hline Jade-AU & $43.63 \mathrm{bc}$ & $22.40 \mathrm{j}$ & $54.40 \mathrm{~g}$ & 40.14 G-I & $31.23 \mathrm{~d}-\mathrm{f}$ & $12.30 \mathrm{~h}$ & $38.97 \mathrm{jk}$ & 27.50 JK \\
\hline Vidiyala & $48.60 \mathrm{a}$ & $29.53 \mathrm{~cd}$ & $61.03 \mathrm{a}-\mathrm{c}$ & 46.39 AB & $36.33 \mathrm{~b}$ & $19.07 \mathrm{~b}$ & $43.90 \mathrm{~b}-\mathrm{e}$ & $33.10 \mathrm{AB}$ \\
\hline Partow & $41.07 \mathrm{~d}-\mathrm{g}$ & $25.30 \mathrm{f}-1$ & $53.90 \mathrm{~g}$ & 40.09 G-I & $30.07 \mathrm{f}-\mathrm{h}$ & $14.20 \mathrm{fg}$ & $39.23 \mathrm{jk}$ & 27.83 I-K \\
\hline Kalkınısh & $36.401-\mathrm{k}$ & $23.07 \mathrm{ij}$ & $61.97 \mathrm{ab}$ & 40.48 F-H & $25.93 \mathrm{kl}$ & $14.10 \mathrm{fg}$ & $45.73 \mathrm{a}$ & 28.59 G-J \\
\hline Ort./Mean & $40.76 \mathrm{~B}$ & $27.89 C$ & $58.83 A$ & & $29.82 \mathrm{~B}$ & $16.35 C$ & $42.17 A$ & \\
\hline
\end{tabular}

Zhai ve ark. (2008), soya fasulyesini farklı hasat dönemlerine göre yaprak, gövde ve tüm bitki olarak hasat etmişlerdir. Araştırmacılar NDF içeriğinin hasat zamanının ilerlemesiyle birlikte arttığını belirlemişler ve en yüksek NDF değerlerini tüm bitkide, en düşük değerleri ise, yapraklarda tespit etmişlerdir. Maş fasulyesi samanının ve bakla kabuklarının NDF içeriği sırasıyla \%55.7 ve \%48.2 olarak belirlenmiştir (Anonymous, 2016). Rohweder ve ark. (1978), yemleri NDF içeriklerine göre; " $<\% 40=$ En üstün kaliteli, $\% 40-46=1$. Kalite (çok iyi), $\% 47-53=2$. Kalite (iyi), $\% 54-60=3$. Kalite (orta), $\% 61-65=4$. Kalite (kötü), $>\% 65=5$. Kalite (kabul edilemez)" olarak sınıflandırmışlardır. Bu sınıflandırmaya göre maş fasulyesi genotiplerinin yapraklarının NDF içeriği 'en üstün kaliteli', gövde kısmının NDF içeriği 'çok iyi', bakla kabuklarının ise 'kötü' gruba girdiği belirlenmiştir. Genotiplerden de 21 B 01 ve 27 S 08 geneotipleri en üstün kaliteli grupta yer almıştır. 
Genotiplerin ADF içeriği \%24.40-34.11 arasında değişiklik göstermiştir. En yüksek ADF oranı 73 A genotipinde, en düşük ise $21 \mathrm{~B} 01$ genotipinde belirlenmiştir. 21 B 01 genotipi ile $27 \mathrm{~S} 08$ genotipi istatistiki olarak aynı grupta yer almıştır. En yüksek ADF içeriği bakla kabuğunda (\%42.17), en düşük ise yaprak kısmında (\% 16.35) tespit edilmiştir. Bitki kısımlarından olan gövdenin ADF içeriği en yüksek 73 A (\%39.00) genotipinde, en düşük ise 21 B 01 (\%21.40) genotipinde tespit edilmiştir. Yaprakların ADF içeriğine bakıldığında $02 \mathrm{G} 05$ genotipi (\%21.20) en yüksek, 21 B 01 genotipi (\%12.23) ise en düşük olarak saptanmıştır. Genotiplerin gövde ve yaprak kısımlarının ADF içeriği tescilli çeşitler göre daha yüksek olduğu belirlenmiştir. Bakla kabukları incelendiğinde en yüksek ADF içeriği Kalkınısh çeşidinde (\%45.73), en düşük ise 27 S 08 genotipinde (\%37.97) belirlenirken Kalkınısh çeşidi ile 65 M 01 ve 73 A genotipleri istatistiki olarak aynı grupta yer almıştır (Tablo 1).

Genel olarak ADF içeriği olgunlaşma ile beraber hücre çeperi bileşenlerinin artması ve yemin sindirilebilirliği düşmektedir. Yapraklar en hızlı sindirilme derecesine sahip olduğundan ve gövde ile sap aksamını içermediğinden lignin tabakasını içermemektedir. Kabuğun lignin içeriği yüksektir ve kabuğun lignin miktarı olgunlaşma ile artmaktadır. Hasat edilen maş fasulyesinde de olgunlaşma tamamlanmış olduğundan lignin içeriği diğer gelişme dönemlerinden daha yüksektir. Bu nedenle bakla kabuklarında da lignin içeriği daha yüksektir.

Nohut bakla kabuklarının NDF ve ADF içerikleri \%56.7-76.0 ve \%46.9-65.2 ve börülce kabuklarının ortalama \%54.2 ve \%41.1 olduğu rapor edilmiştir (Anonymous, 2016). Ravindran (1988), kadife fasulyesinin yem potansiyelini belirlediği çalışmasında, bakla kabuklarının ADF içeriğini \%40.70, hemiselüloz içeriğini \%24.11, selüloz içeriği \%29.80, lignin içeriğini \%8.60, in-vitro şartlarında sindirilebilir organik madde miktarını $\% 42.23$ olarak saptamıştır. Elde ettikleri veriler sonucunda, kadife fasulyesinin düşük yem kalitesine sahip olduğunu belirtmiştir. Maş fasulyesinin hasat artıklarının NDF özellikleri literatürlerle kıyaslandığında bakla kabuğunun NDF içeriğinin oldukça yüksek; yaprağın ise düşük olduğu belirlenmiştir. ADF içerikleri ise börülce ile aynı familyadan olan maş fasulyesinin bakla kabuklarıyla benzer değerleri almıştır. Soya fasulyesi ile yapılan çalışmada yaprak, gövde ve bütün bitkinin ADF konsantrasyonlarının hasat tarihlerinin gecikmesi ile arttı̆̆ bildirilmiştir (Sherasia ve ark., 2017). Rohweder ve ark. (1978), yem değerini ADF oranına göre; "<\%31= En üstün kaliteli, $\% 31-35=1$. Kalite (çok iyi), $\% 36-40=2$. Kalite (iyi), $\% 41-42=3$. Kalite (orta), $\% 43-45=4$. Kalite (kötü), $>\% 45=5$. Kalite (kabul edilemez)" olarak sınıflandırmıştır. Bu sınıflandırmaya göre; ADF oranları bakımından, araştırmada incelenen maş fasulyesi genotiplerinin gövde ve yaprak kısımlarının "en üstün kaliteli", bakla kabuklarının ise "3. kalite (orta kalite)" olduğu ve genotiplerin ortalamaları incelendiğinde genel olarak "en üstün kaliteli" ve "1. kalite" yem değerine sahip oldukları belirlenmiştir.

\subsection{ADL ve Selüloz İçeriği}

Genotiplerin ADL içerikleri \%6.19-9.93 arasında değişim göstermiştir. En yüksek ADL değeri 73 A genotipinde belirlenmiş olup, 73 A genotipi 02 G 05, 07 A 02, 33 M 02, 46 G 01, 73 C genotipleri ve Vidiyala çeşidi ile istatistiki olarak aynı grupta yer almışlardır. Çalışmada en düşük ADL içeriği ise $60 \mathrm{M} 01$ genotipinde gözlemlenmiş̧ir. En yüksek ADL içeriği bakla kabuklarında (\%12.28), en düşük değer ise yaprak (\%4.95) kısmında tespit edilmiştir. Gövde kısmının ADL içeriği \%5.50-10.13 arasında değişim göstermiştir. Gövdenin ADL içeriği en yüksek 73 A genotipinde, en düşük ise $50 \mathrm{~N} 01$ genotipinde tespit edilmiştir. 73 A genotipi ile Vidiyala çeşidi arasında istatistiki olarak bir farklılık bulunamamıştır. Yaprakların ADL içeriğine bakıldığında Vidiyala çeşidinde (\%6.50) en yüksek, $60 \mathrm{M} 01$ genotipinde ise en düşük değere sahip olmuştur. Vidiyala çeşidi Adıyaman, Antalya (07 A 02, 07 A 05, 07 G 01, 07 G 09), Mersin, Niğde, Van, Şırnak ve Kilis’ten elde edilen genotipler ile aynı istatistiki grupta yer almıştır. Bakla kabukları incelendiğinde ise, en yüksek değer \%15.33 ile 21 B 01 genotipinde, en düşük değer ise $\% 10.70$ ile 60 M 01 genotipinde tespit edilmiştir. 21 B 01 genotipi Kalkınısh çeşidi ile aynı istatistiki grupta yer almıştır (Tablo 2).

ADL, bitkilerin sindirilmeyen kısmı olup, lignin miktarın ifade etmektedir. Hücre duvarı gelişimine paralel olarak bitkiler de gelişmekte ve lif içeren bileşiklerin ADL oranı artmaktadır (Frost ve ark., 2008; Oktay ve Temel, 2015). Lignin maddesi, bitki gövdesinin sertleşmesine sebep olmasından dolayı, yaprak ve çiçeklere göre gövdede daha fazladır (Açıkgöz, 2001). Bitkilerin yapısında bulunan ve sindirimi yavaşlatan NDF, ADF ve ADL seviyelerinin artması ile fiziksel olarak hayvanın tokluk hissetmesine neden olmakta ve böylece hayvanların yem tüketimini sınırlanmakta olduğu bildirilmekte ve ayrıca yemlerin ADF ve ADL oranlarının düşük olması istenmektedir (Van Soest, 1994). Bitkilerin olgunlaşması ile sap/yaprak oranı ve ADL içeriği artmakta ve buna paralel olarak da besin madde kaybı yaşandığı belirtilmiştir (Kamalak, 2006). 
Karaman \& Türkay \& Kaya

Maş Fasulyesi Tohum Hasadı Artıklarının Hayvan Beslemede Kullanılabilme Potansiyeli

Sreerengaraju ve ark. (2000), nohut kabuklarının ADL içeriğini \%6.10 olarak bildirmiştir. Maş fasulyesi samanı üzerinde yapılan literatür taraması sonuçlarına göre ADL içeriği \%4.8 (Anonymous, 2016) ve \%3.7-8.4 (Nair ve ark., 2019) arasında değişim göstermektedir. Bruno-Soares ve ark. (2000), nohut, fiğ, tüylü fĭğ, bakla, mercimek, bezelye ve mor fiğ samanının ADL içeriklerini sırasıyla \%14.2, \%10.1, \%11.4, \%12.8, \%13.3, \%8.2 ve \%13.1 olarak tespit etmişlerdir. Yapılan çalışmalarda maş fasulyesi samanında ADL içerikleri (\%3.7-8.4 ), bakla kabuklarını içermemekte, bu nedenle elde ettiğimiz bulgular gövde ve yaprak değerleri literatürler ile uyun içerisindedir. Yapılan çalışmalar sonucunda, ADL içeriği genotip ve tür, bitkinin kısmı, vejetasyon dönemi, fiziksel ve kimyasal uygulamalara göre değişim göstermektedir. Bu sonuçlar yapılan çalışmayı destekler niteliktedir.

Genotiplerin ortalama selüloz içerikleri \%15.92-24.17 arasında değişim göstermiştir. En yüksek selüloz içeriği 73 A genotipinde, en düşük değer ise 21 B 01 genotipinde belirlenmiştir. Bitki kısımlarının selüloz içerikleri gövdede ortalama \%22.76, yaprak \%11.4 ve bakla kısmında \%29.88 olarak tespit edilmiştir. Selüloz içeriği, gövde kısmında en yüksek selüloz içeriği 73 A genotipinde (\%28.89), yaprakta 07 G 09 genotipinde (\%15.73) ve bakla kabuklarında ise $65 \mathrm{M} 01$ genotipinde (\%32.27) belirlenirken, en düşük selüloz içeriği her üç bitki kısmında da 21 B 01 genotipinde tespit edilmiştir (Tablo 2).

Tablo 2. Maş fasulyesi genotip ve çeşitlerinin bitki kısımlarına göre ADL ve selüloz içerikleri

Table 2. ADL and cellulose contents of mung bean genotype and varieties according to plant parts

\begin{tabular}{|c|c|c|c|c|c|c|c|c|}
\hline \multirow{2}{*}{$\begin{array}{c}\text { Genotip/ } \\
\text { Çeşit } \\
\text { Genotype/ } \\
\text { Variety }\end{array}$} & \multicolumn{4}{|c|}{$\begin{array}{c}\text { ADL İçeriği (\%) } \\
\text { ADL Content }\end{array}$} & \multicolumn{4}{|c|}{$\begin{array}{l}\text { Selüloz İçeriği (\%) } \\
\text { Cellulose Content }\end{array}$} \\
\hline & $\begin{array}{l}\text { Gövde } \\
\text { Stem }\end{array}$ & $\begin{array}{c}\text { Yaprak } \\
\text { Leaf }\end{array}$ & $\begin{array}{c}\text { Bakla } \\
\text { kabuğu } \\
\text { Pod husk } \\
\end{array}$ & $\begin{array}{c}\text { Ort. } \\
\text { Mean }\end{array}$ & $\begin{array}{l}\text { Gövde } \\
\text { Stem }\end{array}$ & $\begin{array}{c}\text { Yaprak } \\
\text { Leaf }\end{array}$ & $\begin{array}{c}\text { Bakla } \\
\text { kabuğu } \\
\text { Pod husk }\end{array}$ & $\begin{array}{c}\text { Ort. } \\
\text { Mean }\end{array}$ \\
\hline 02 G 05 & $7.30 \mathrm{~b}-\mathrm{h}$ & $5.83 \mathrm{a}-\mathrm{d}$ & $14.13 \mathrm{ab}$ & $9.09 \mathrm{~A}-\mathrm{C}$ & $25.53 \mathrm{~b}$ & $15.33 \mathrm{ab}$ & $28.53 \mathrm{~g}-1$ & $23.13 \mathrm{~A}-\mathrm{C}$ \\
\hline 07 A 02 & $8.40 \mathrm{bc}$ & $5.30 \mathrm{a}-\mathrm{g}$ & $12.27 \mathrm{c}-\mathrm{f}$ & 8.66 A-D & $25.20 \mathrm{bc}$ & 9.37 h1 & $29.33 \mathrm{f}-\mathrm{h}$ & 21.30 D-I \\
\hline 07 A 05 & $6.97 \mathrm{~d}-\mathrm{j}$ & $5.20 \mathrm{a}-\mathrm{g}$ & $12.00 \mathrm{c}-\mathrm{f}$ & 8.06 B-E & $21.50 \mathrm{~g}-1$ & $13.03 \mathrm{~cd}$ & $31.17 \mathrm{a}-\mathrm{d}$ & 21.90 C-H \\
\hline 07 G 01 & $6.33 \mathrm{e}-\mathrm{j}$ & $6.10 \mathrm{ab}$ & $11.63 \mathrm{~d}-\mathrm{f}$ & 8.02 B-E & $22.97 \mathrm{e}-\mathrm{g}$ & $11.93 \mathrm{c}-\mathrm{e}$ & $31.70 \mathrm{a}-\mathrm{c}$ & 22.20 C-G \\
\hline 07 G 08 & $7.70 b-f$ & $3.77 \mathrm{~g}$ & $12.03 \mathrm{c}-\mathrm{f}$ & $7.83 \mathrm{~B}-\mathrm{F}$ & $25.70 \mathrm{~b}$ & $11.83 \mathrm{de}$ & 29.50 e-h & 22.34 B-F \\
\hline 07 G 09 & $8.13 \mathrm{~b}-\mathrm{d}$ & $5.37 \mathrm{a}-\mathrm{f}$ & $12.10 \mathrm{c}-\mathrm{f}$ & 8.53 EF & $22.30 \mathrm{f}-\mathrm{h}$ & $15.73 \mathrm{a}$ & $29.27 \mathrm{f}-\mathrm{h}$ & $22.43 \mathrm{~A}-\mathrm{F}$ \\
\hline 21 B 01 & $5.60 \mathrm{ij}$ & $4.53 \mathrm{~b}-\mathrm{g}$ & $15.33 \mathrm{a}$ & 8.49 D-F & $15.80 \mathrm{k}$ & $7.70 \mathrm{j}$ & $24.27 \mathrm{j}$ & $15.92 \mathrm{~L}$ \\
\hline 27 N 01 & $5.90 \mathrm{~g}-\mathrm{j}$ & $4.13 \mathrm{e}-\mathrm{g}$ & $11.00 \mathrm{ef}$ & $7.01 \mathrm{EF}$ & $19.90 \mathrm{ij}$ & 10.60 e-h & $29.17 \mathrm{f}-\mathrm{h}$ & 19.89 IJ \\
\hline $27 \mathrm{~S} 01$ & $5.60 \mathrm{j}$ & $4.56 \mathrm{~b}-\mathrm{g}$ & $11.83 \mathrm{~d}-\mathrm{f}$ & $7.33 \mathrm{D}-\mathrm{F}$ & $18.80 \mathrm{j}$ & $10.10 \mathrm{f}-1$ & 29.70 d-h & 19.53 JK \\
\hline $27 \mathrm{~S} 08$ & $6.50 e-j$ & $4.20 \mathrm{~d}-\mathrm{g}$ & 10.73 ef & 7.14 D-F & $17.27 \mathrm{k}$ & 9.40 h1 & 27.201 & $17.96 \mathrm{~K}$ \\
\hline 33 M 02 & $7.53 b-f$ & $6.10 \mathrm{ab}$ & $12.00 \mathrm{c}-\mathrm{f}$ & 8.54 A-E & $25.00 \mathrm{~b}-\mathrm{d}$ & 10.80 e-h & $30.60 \mathrm{~b}-\mathrm{f}$ & 22.13 C-G \\
\hline 46 G 01 & $7.17 b-1$ & $4.50 \mathrm{~b}-\mathrm{g}$ & $14.07 \mathrm{ab}$ & 8.58 A-E & $20.27 \mathrm{ij}$ & $12.50 \mathrm{~cd}$ & $30.00 \mathrm{c}-\mathrm{g}$ & 20.92 E-J \\
\hline 50 N 01 & $5.50 \mathrm{j}$ & $4.83 \mathrm{a}-\mathrm{g}$ & $11.83 \mathrm{~d}-\mathrm{f}$ & $7.39 \mathrm{C}-\mathrm{F}$ & $20.17 \mathrm{ij}$ & 10.67 e-h & $31.70 \mathrm{ab}$ & 20.84 F-J \\
\hline 60 M 01 & $5.87 \mathrm{~g}-\mathrm{j}$ & $2.00 \mathrm{~h}$ & $10.70 \mathrm{f}$ & $6.19 \mathrm{~F}$ & $23.30 \mathrm{ef}$ & $13.60 \mathrm{bc}$ & $31.10 \mathrm{a}-\mathrm{e}$ & 22.67 A-D \\
\hline 65 M 01 & $6.07 \mathrm{f}-\mathrm{j}$ & 5.50 a-e & $12.33 \mathrm{c}-\mathrm{e}$ & 7.97 B-E & $23.20 \mathrm{e}-\mathrm{g}$ & $11.30 \mathrm{~d}-\mathrm{g}$ & $32.27 \mathrm{a}$ & $22.26 \mathrm{C}-\mathrm{F}$ \\
\hline $73 \mathrm{~A}$ & $10.13 \mathrm{a}$ & $5.63 \mathrm{a}-\mathrm{e}$ & $14.03 \mathrm{ab}$ & $9.93 \mathrm{~A}$ & $28.87 \mathrm{a}$ & $12.90 \mathrm{~cd}$ & 30.73 b-f & 24.17 A \\
\hline $73 \mathrm{C}$ & $7.40 \mathrm{~b}-\mathrm{g}$ & $5.90 \mathrm{a}-\mathrm{c}$ & $13.03 \mathrm{~b}-\mathrm{d}$ & 8.78 A-D & $21.03 \mathrm{~h} 1$ & 10.73 e-h & $29.90 \mathrm{~d}-\mathrm{g}$ & 20.56 G-J \\
\hline 79 М 01 & $6.90 \mathrm{c}-\mathrm{j}$ & $6.10 \mathrm{ab}$ & $11.77 \mathrm{~d}-\mathrm{f}$ & 8.26 B-E & $24.67 \mathrm{~b}-\mathrm{e}$ & $11.50 \mathrm{~d}-\mathrm{f}$ & $31.57 \mathrm{a}-\mathrm{c}$ & 22.58 B-E \\
\hline 79 М 02 & $8.30 \mathrm{~b}-\mathrm{d}$ & $5.30 \mathrm{a}-\mathrm{f}$ & $10.93 \mathrm{ef}$ & 8.18 B-E & $27.60 \mathrm{a}$ & $12.57 \mathrm{~cd}$ & 30.47 b-f & $23.54 \mathrm{~A}-\mathrm{C}$ \\
\hline Jade-AU & $7.80 \mathrm{~b}-\mathrm{e}$ & $3.80 \mathrm{fg}$ & $11.90 \mathrm{~d}-\mathrm{f}$ & 7.83 B-E & $23.47 \mathrm{c}-\mathrm{f}$ & $8.47 \mathrm{ij}$ & 27.071 & 19.67 I-K \\
\hline Vidiyala & $8.80 \mathrm{ab}$ & $6.50 \mathrm{a}$ & $11.97 \mathrm{~d}-\mathrm{f}$ & $9.09 \mathrm{AB}$ & $27.57 \mathrm{a}$ & $12.57 \mathrm{~cd}$ & $31.90 \mathrm{ab}$ & 24.01 AB \\
\hline Partow & $6.80 c-j$ & $4.47 \mathrm{c}-\mathrm{g}$ & 11.07 ef & $7.44 \mathrm{C}-\mathrm{F}$ & $23.30 \mathrm{~d}-\mathrm{f}$ & $9.70 \mathrm{~g}-1$ & $28.13 \mathrm{~h} 1$ & 20.38 H-J \\
\hline Kalkınısh & $5.73 \mathrm{~h}-\mathrm{j}$ & $4.30 \mathrm{c}-\mathrm{g}$ & $13.67 \mathrm{a}-\mathrm{c}$ & 7.90 B-E & $20.17 \mathrm{ij}$ & $9.87 \mathrm{f}-1$ & $32.07 \mathrm{ab}$ & 20.70 F-J \\
\hline Ort./Mean & $7.06 \mathrm{~B}$ & $4.95 C$ & $12.28 \mathrm{~A}$ & & $22.76 \mathrm{~B}$ & $11.40 \mathrm{C}$ & $29.88 \mathrm{~A}$ & \\
\hline
\end{tabular}

Selüloz, glikoz ünitelerinin $\beta-1,4$ bağları ile bağlanması sonucu oluşan bir polimerdir. Hücre duvarının yapısında fazla miktarda bulunan selüloz, yapısal bir karbonhidrat olup, bitkiye sağlamlık vermektedir (Mendu ve ark., 2011). Ham selüloz, selüloz, lignin ve hemiselüloz maddelerinden oluşmaktadır (Budak ve Budak, 2014). Geviş getiren hayvanların rumenlerinde yaşayan bazı mikroorganizmaların yaşamlarını devam ettirip çoğalabilmeleri için bu hayvanların rasyonlarının yüksek düzeyde selüloz içermesi gerekmektedir. Bitki olgunlaştıkça, içerisindeki selüloz miktarı artmakta ve dolgu maddesi özelliği kazanmaktadır. Ruminantların 
rasyonlarında dolgu maddesi yeteri kadar bulunduğu zaman, düzenli bir sindirim ile mekanik doyum sağlanmaktadır. Özellikle süt sığırı rasyonlarının kuru maddesinde \%18-22 oranında ham selüloz bulunması gerekmektedir. (Erener ve ark., 2016). Yapılan çalışma sonuçlarına göre maş fasulyesinin yapraklarının süt sığırı beslenmesinde kaba yem olarak kullanılabileceği öngörülmektedir.

Ravindran (1988), kadife fasulyesi çeşitlerinde bakla kabuklarının selüloz içeriğini \%29.80 ve hasat günlerine göre selüloz içeriğini ise, \%27.85-37.50 arasında değişim gösterdiğini ifade etmiştir. Venkateswarlu ve ark., (2013), güvercin bezelyesi samanının selüloz içeriğini \%47.58, mısır koçanının selüloz içeriğini \%58.2 ve Vigna mungo samanının selüloz içeriğini \%54.6 olarak belirlemişlerdir. Literatür taraması yapıldığında maş fasulyesi samanının selüloz içeriği genel olarak diğer bitkilere nazaran daha düşük olduğu belirlenmiştir.

\subsection{TSBM içeriği ve Nisbi yem değeri}

Bitki kısımlarının TSBM değerleri \%46.91-80.25 arasında değişim göstermiştir. En yüksek TSBM değeri yaprak kısmında; en düşük, bakla kabuklarında belirlenmiştir. Genotiplerin ortalama TSBM içeriği \%57.30-69.84 arasında değişmiş ve en yüksek TSBM içeriği 21 B 01 genotipinde belirlenmiştir. 21 B 01 genotipi ile 27 S 08 genotipi arasında istatistiksel olarak önemli bir fark bulunmazken, 73 A genotipi en düşük TSBM değerine sahip olmuştur. Bitki kısımlarından olan gövde ve yaprağın TSBM içeriği en yüksek 21 B 01 genotipinde (sırasıyla \%73.73 ve \%85.53), en küçük ise 73 A genotipinde (sırasıyla \%51.0 ve \%77.4) tespit edilmiştir. Bakla kabuklarında en yüksek TSBM içeriği 27 S 08 (\%52.37) genotipinde, en düşük ise Kalkınısh çeşidinde belirlenmiştir. 27 S 08 genotipi ile Partow ve Jade-AU çeşitleri ile arasında istatistiksel olarak önemli bir fark bulunmamıştır (Tablo 3).

Tablo 3. Maş fasulyesi genotip ve çeşitlerinin bitki kısımlarına göre TSBM ve NYD

Table3. TSBM and NYD by plant parts of mung bean genotype and cultivars

\begin{tabular}{|c|c|c|c|c|c|c|c|c|}
\hline \multirow{2}{*}{$\begin{array}{l}\text { Genotip/ } \\
\text { Çeşit } \\
\text { Genotype/ } \\
\text { Variety }\end{array}$} & \multicolumn{4}{|c|}{$\begin{array}{c}\text { TSBM İçeriği (\%) } \\
\text { TDN Content }\end{array}$} & \multicolumn{4}{|c|}{$\begin{array}{c}\text { NYD } \\
R F V\end{array}$} \\
\hline & $\begin{array}{l}\text { Gövde } \\
\text { Stem }\end{array}$ & $\begin{array}{l}\text { Yaprak } \\
\text { Leaf }\end{array}$ & $\begin{array}{c}\text { Bakla } \\
\text { kabuğu } \\
\text { Pod husk }\end{array}$ & $\begin{array}{l}\text { Ort. } \\
\text { Mean }\end{array}$ & $\begin{array}{l}\text { Gövde } \\
\text { Stem }\end{array}$ & $\begin{array}{l}\text { Yaprak } \\
\text { Leaf }\end{array}$ & $\begin{array}{c}\text { Bakla } \\
\text { kabuğu } \\
\text { Pod husk }\end{array}$ & $\begin{array}{c}\text { Ort. } \\
\text { Mean }\end{array}$ \\
\hline 02 G 05 & $59.00 \mathrm{jk}$ & $74.00 \mathrm{~h}$ & $46.27 \mathrm{~d}-\mathrm{g}$ & $59.76 J K$ & $138.40_{1-\mathrm{k}}$ & 228.231 & 87.90 a-c & $151.51 \mathrm{G}-I$ \\
\hline 07 A 02 & $58.00 \mathrm{k}$ & $82.43 \mathrm{bc}$ & $47.63 \mathrm{~cd}$ & $62.69 F-H$ & $130.57 \mathrm{kl}$ & $264.50 \mathrm{~d}-\mathrm{f}$ & 90.67 a-c & $161.91 \mathrm{D}-H$ \\
\hline 07 A 05 & $64.60 \mathrm{e}-\mathrm{g}$ & $77.83 \mathrm{fg}$ & 45.60 e-h & $62.68 F-H$ & $157.53 \mathrm{~d}-\mathrm{h}$ & 239.53 h1 & $85.20 \mathrm{a}-\mathrm{c}$ & $160.76 \mathrm{D}-I$ \\
\hline 07 G 01 & $63.53 \mathrm{f}-\mathrm{h}$ & $78.10 \mathrm{fg}$ & $45.43 \mathrm{e}-1$ & $62.36 F-I$ & $158.20 \mathrm{~d}-\mathrm{g}$ & $183.00 \mathrm{k}$ & $85.10 \mathrm{a}-\mathrm{c}$ & $142.10 \mathrm{I}$ \\
\hline 07 G 08 & $58.30 \mathrm{k}$ & 81.20 c-e & $47.73 \mathrm{~cd}$ & $62.41 F-I$ & $135.00 \mathrm{kl}$ & $257.20 \mathrm{f}-\mathrm{h}$ & $91.50 \mathrm{a}-\mathrm{c}$ & $161.23 \mathrm{D}-I$ \\
\hline 07 G 09 & $62.00 \mathrm{~h} 1$ & $74.10 \mathrm{~h}$ & $47.93 \mathrm{~cd}$ & $61.34 H-J$ & 140.37 h-k & $208.47 \mathrm{j}$ & $91.60 \mathrm{a}-\mathrm{c}$ & $146.81 \mathrm{HI}$ \\
\hline 21 B 01 & $73.73 \mathrm{a}$ & $85.53 \mathrm{a}$ & $50.27 \mathrm{~b}$ & $69.84 A$ & $199.20 \mathrm{a}$ & 265.87 ef & $97.83 \mathrm{a}-\mathrm{c}$ & $187.63 A B$ \\
\hline 27 N 01 & $68.10 \mathrm{c}$ & $82.40 \mathrm{bc}$ & $49.50 \mathrm{bc}$ & $66.67 B$ & $172.60 \mathrm{c}-\mathrm{e}$ & $267.70 \mathrm{c}-\mathrm{f}$ & $93.0 \mathrm{a}-\mathrm{c}$ & $177.79 A-D$ \\
\hline 27 S 01 & $69.80 \mathrm{bc}$ & $82.47 \mathrm{bc}$ & $47.80 \mathrm{~cd}$ & $66.69 \mathrm{~B}$ & $178.07 \mathrm{c}$ & $283.10 b-d$ & 90.10 a-c & $183.76 \mathrm{~A}-\mathrm{C}$ \\
\hline 27 S 08 & $70.60 \mathrm{~b}$ & $83.80 \mathrm{ab}$ & $52.37 \mathrm{a}$ & $68.92 A$ & $194.83 \mathrm{ab}$ & $282.93 \mathrm{~b}-\mathrm{e}$ & $102.60 \mathrm{a}$ & $193.46 \mathrm{~A}$ \\
\hline 33 М 02 & $59.33 \mathrm{jk}$ & $79.60 \mathrm{~d}-\mathrm{f}$ & $46.30 \mathrm{~d}-\mathrm{f}$ & $61.74 G-J$ & $137.831-\mathrm{k}$ & $243.53 \mathrm{~g}-1$ & $87.57 \mathrm{a}-\mathrm{c}$ & $156.31 \mathrm{E}-I$ \\
\hline 46 G 01 & $65.97 \mathrm{de}$ & 79.40 ef & $44.43 \mathrm{~g}-1$ & $63.27 E-H$ & $155.43 \mathrm{e}-1$ & $275.90 \mathrm{~b}-\mathrm{f}$ & $82.10 \mathrm{bc}$ & $171.14 B-F$ \\
\hline 50 N 01 & $68.20 \mathrm{c}$ & $81.37 \mathrm{~cd}$ & $45.10 \mathrm{f}-1$ & $64.89 B-E$ & 178.90 bc & $287.80 \mathrm{~b}$ & $84.67 \mathrm{a}-\mathrm{c}$ & $183.79 A B$ \\
\hline 60 M 01 & $63.73 \mathrm{f}-\mathrm{h}$ & 81.20 c-e & $47.33 \mathrm{de}$ & $64.09 C-F$ & $166.03 \mathrm{c}-\mathrm{f}$ & $259.27 \mathrm{fg}$ & $88.30 \mathrm{a}-\mathrm{c}$ & $171.20 \mathrm{~B}-\mathrm{E}$ \\
\hline 65 M 01 & $63.57 \mathrm{f}-\mathrm{h}$ & $79.67 \mathrm{~d}-\mathrm{f}$ & $43.77 \mathrm{~h}-\mathrm{j}$ & $62.33 G-I$ & $154.53 \mathrm{e}-\mathrm{j}$ & $263.47 \mathrm{f}$ & $80.20 \mathrm{c}$ & $166.07 C-G$ \\
\hline $73 \mathrm{~A}$ & $51.00 \mathrm{~m}$ & $77.40 \mathrm{~g}$ & $43.50 \mathrm{ij}$ & $57.30 \mathrm{~L}$ & $110.23 \mathrm{~m}$ & 234.801 & $81.17 \mathrm{c}$ & $142.07 I$ \\
\hline $73 \mathrm{C}$ & $64.60 \mathrm{ef}$ & $79.90 \mathrm{~d}-\mathrm{f}$ & $45.93 \mathrm{~d}-\mathrm{g}$ & $63.48 D-G$ & $155.90 \mathrm{e}-1$ & $243.20 \mathrm{~g}-1$ & $86.00 \mathrm{a}-\mathrm{c}$ & $161.70 \mathrm{D}-\mathrm{H}$ \\
\hline 79 M 01 & $60.63 \mathrm{ij}$ & $78.60 \mathrm{fg}$ & $45.40 \mathrm{f}-1$ & $61.54 H-J$ & $144.13 \mathrm{~g}-\mathrm{k}$ & 228.771 & $84.77 \mathrm{a}-\mathrm{c}$ & $152.56 \mathrm{~F}-I$ \\
\hline 79 М 02 & 55.031 & $78.23 \mathrm{fg}$ & $47.90 \mathrm{~cd}$ & $60.39 I-K$ & $118.40 \mathrm{~lm}$ & $258.10 \mathrm{f}-\mathrm{h}$ & 90.03 a-c & $155.51 \mathrm{E}-I$ \\
\hline Jade-AU & $61.00 \mathrm{ij}$ & $85.50 \mathrm{a}$ & $51.03 \mathrm{ab}$ & $65.84 B C$ & $137.67 \mathrm{jk}$ & $329.40 \mathrm{a}$ & $100.10 \mathrm{ab}$ & $189.06 A B$ \\
\hline Vidiyala & 54.431 & $76.77 \mathrm{~g}$ & $44.70 \mathrm{f}-1$ & $58.63 \mathrm{KL}$ & $116.00 \mathrm{~lm}$ & 233.831 & $83.40 \mathrm{bc}$ & $144.41 \mathrm{HI}$ \\
\hline Partow & $62.53 \mathrm{~g}-1$ & $83.03 \mathrm{bc}$ & $50.70 \mathrm{ab}$ & $65.42 B-D$ & $148.37 \mathrm{f}-\mathrm{k}$ & $286.73 \mathrm{bc}$ & $100.63 \mathrm{ab}$ & $178.58 \mathrm{~A}-\mathrm{D}$ \\
\hline Kalkınısh & $67.87 \mathrm{~cd}$ & $83.10 \mathrm{bc}$ & $42.30 \mathrm{j}$ & $64.42 C-F$ & $175.80 \mathrm{~b}-\mathrm{d}$ & $314.33 \mathrm{a}$ & $79.97 \mathrm{c}$ & $190.03 A B$ \\
\hline Ort./Mean & $62.85 \mathrm{~B}$ & $80.25 \mathrm{~A}$ & $46.91 \mathrm{C}$ & & $152.35 \mathrm{~B}$ & $258.25 \mathrm{~A}$ & $88.89 C$ & \\
\hline
\end{tabular}


Abreu ve Bruno-Soares (1998), nohut, mercimek, bezelye, bakla samanlarının TSBM \%45.1, \%46.6, \%55.3 ve \% 48.3 olduğunu tespit etmişlerdir. Rasby ve ark. (2008), soya fasulyesinin bitki kısımlarının TSBM değerini belirledikleri çalışmada; yapraklarının \%38, gövdesinin \%35, baklasının \%41, tohumlarının \%92 oranında değerlere sahip olduğunu belirlemişlerdir. El-Salam ve ark. (2013), Hindistan'da maş fasulyesi çeşitlerinin yem potansiyelini belirledikleri çalışmalarında, TSBM verim değerlerinin 1.87-2.63 ton/fed. arasında değişism gösterdiğini ve çeşitlere göre TSBM verim değerlerinin değiştiğini ifade etmişlerdir. Karaman (2019), Türkiye'den ve yurt dışından temin ettiği maş fasulyesi tohum genotip ve çeşitlerinin TSBM değerlerini birinci yı1 \%76.4-84.27, ikinci yıl ise, \%74.98-90.35 arasında değişim gösterdiğini ve genotip ile çeşitlere göre değiştiğini saptamıştır. Bhardwaj (2013), Virjinya'da Phaseolus acutifolius türlerinin yem potansiyelini belirlediği çalışmada; TSBM'nin \%55.9-65.9 arasında değerler aldığını rapor etmişlerdir. Maş fasulyesi bitki kısımları karşılaştırıldığında yaprakları diğer kısımlara nazaran daha yüksek değerlere sahip olmuş olup, bu durum literatürce desteklenmektedir (Rasby ve ark., 2008).

Genotiplerin nisbi yem değerleri (NYD) 142.07-193.46 arasında değişim göstermiştir. En yüksek NYD $27 \mathrm{~S}$ 08 genotipinde belirlenmiş olup, 27 S 08 genotipi 21 B 01, 27 N 01, 27 S 01, 50 N 01 genotipleri; Jade-AU, Partow ve Kalkınısh çeşitleri ile istatistiki olarak aynı grupta yer almıştır. 73 A genotipi ise, en düşük NYD değerine sahip olup, 07 G 01 genotipi arasında istatistiksel olarak önemli bir fark bulunamamıştır. Bitki kısımlarının NYD içerikleri gövde kısmında 152.35, yaprak kısmında 258.25 ve bakla kabuklarında 88.95 olarak belirlenmiştir. Gövde kısmının NYD en fazla 199.2 ile 21 B 01 genotipinde tespit edilirken, 194.83 ile 27 S 08 genotipi ile 21 B 01 genotipi istatistiki olarak aynı grupta yer almışlardır. En küçük NYD içeriğine ise 73 A genotipi (110.23) sahip olmuştur. Genotiplerin ve çeşitlerin yapraklarının NYD’ne bakıldığında yüksek Jade-AU çeşidi olurken, Jade-AU çeşidi Kalkınısh çeşidi ile istatistiki olarak aynı grupta yer almıştır. NYD yaprakta en küçük 07 G 01 genotipinde tespit edilmiştir. Diğer bir bitki kısmı olan bakla kabuğunun NYD en yüksek 27 S 08 (193.46) genotipinde, en düşük ise Kalkınısh çeşidinde (79.97) belirlenmiştir (Tablo 3).

Kaba yemlerin yem kalitesini gösteren ölçütlerden birisi nisbi yem değeridir. NYD, yemlerin alımı ve enerji değerinin tahmini için kullanılan bir özelliktir. NYD değeri için yonca 100 olarak alınmakta ve NYD 100'ün altına düştükçe yem kalitesi düşmekte, yükselmesi durumunda ise artmaktadır (Moore ve Undersander, 2002). Nisbi yem değeri 75' in altında ise 5. kalite, 75-86 ise 4. kalite, 87-102 ise 3. kalite, 103-124 ise 2. kalite, 125-150 ise 1. kalite ve 150'nin üzerinde ise en iyi kalite olarak kabul edilmektedir (Rohweder ve ark., 1978). Bu veriler göz önüne alındığında en düşük NYD‘ine sahip bakla kabuklarının 3. kalite olduğu belirlenmiştir. Bunun yanında gövdenin (152.35) ve yaprak (258.25) en iyi kalitede olduğu saptanmış ve maş fasulyesinin bitki kısımlarının yem potansiyelinin yüksek olduğu düşünülmektedir. Karaman ve ark. (2020), maş fasulyesi genotiplerinin farklı hasat dönemlerinde hasat etmişler ve genotiplerin NYD’lerini 179.8-228.9 arasında değişim gösterdiğini ve ekimden 45 gün sonra yapılan hasat zamanında en yüksek NYD elde etmişlerdir. Ayrıca araştırmacılar, yoncanın NYD‘si 100 olarak kabul edildiğinde, maş fasulyesi genotiplerinin NYD değerlerinin oldukça yüksek ve iyi kalitede olduğu tespit etmişlerdir.

\subsection{Metabolik enerji içeriği}

Maş fasulyesi genotiplerinin ME değeri en yüksek 21 B 01 (9.89 $\left.\mathrm{MJ} \mathrm{kg}^{-1}\right)$ genotipinde, en düşük 73 A (8.61 $\mathrm{MJ} \mathrm{kg}^{-1}$ ) genotipinde belirlenmiştir. En yüksek ME değerine sahip olan $21 \mathrm{~B} 01$ genotipi ile $27 \mathrm{~S} 08$ genotipi aynı istatistiki grupta yer almıştır. Bitki kısımlarının ME değerleri incelendiğinde en yüksek yaprak kısmında; en düşük bakla kabuklarında belirlenmiştir. ME içeriği gövdede en yüksek $21 \mathrm{~B} 01$ (10.27 MJ kg-1) genotipinde, en düşük ise $73 \mathrm{~A}\left(7.97 \mathrm{MJ} \mathrm{kg}^{-1}\right.$ ) genotipinde tespit edilmiştir. Genotiplerin gövde kısmının ME içeriği tescilli çeşitlere göre daha yüksek olduğu belirlenmiştir. Yaprakların ME içeriği en yüksek $11.50 \mathrm{MJ} \mathrm{kg}^{-1}$ ile $21 \mathrm{~B} 01$ genotipinde ve Jade-AU çeşidinde tespit edilirken, 27 S 08 genotipi ile aralarında istatistiksel olarak önemli bir fark bulunamamıştır. En düşük yaprakta $\mathrm{ME}$ içeriği ise $10.30 \mathrm{MJ} \mathrm{kg}^{-1}$ ile $02 \mathrm{G} 05$ ve $07 \mathrm{G} 09$ genotiplerinde belirlenmiştir. Diğer bir bitki kısmı olan bakla kabuğunun ME içeriği en yüksek $27 \mathrm{~S} 08$ genotipinde $(8.10 \mathrm{MJ}$ kg${ }^{1}$ ), en düşük ise Kalkınısh çeşidinde (7.10 $\mathrm{MJ} \mathrm{kg}^{-1}$ ) belirlenmiştir. Bakla kabukları için genotipler ile çeşitler kıyaslandığında Jade-AU ve Partow çeşitleri en yüksek ME içeriklerine sahip olan 27 S 08 genotipi ile aynı istatistiki grupta yer almıştır (Tablo 4).

Abreu ve Bruno-Soares (1998), nohut, bakla, mercimek ve bezelye samanlarının ME değerlerinin sirasıyla 6.1, 6.2, 6.2 ve $7.1 \mathrm{MJ} \mathrm{kg}^{-1}$ olduğunu belirledikleri çalışmada, Metabolik enerjinin türlere göre değiştiğini ifade 
etmişlerdir. Karabulut ve ark. (2007), yonca samanının ME’ni 10.46 MJ kg-1, bezelyenin 10.27 MJ kg-1 nohudun $9.09 \mathrm{MJ} \mathrm{kg}^{-1}$ olarak belirlemişlerdir. Nair ve ark. (2015), 21 adet maş fasulyesinin yem değerlerini belirledikleri çalışmada, ME değerlerini 7.8-8.9 $\mathrm{MJ} \mathrm{kg}^{-1}$ arasında değiştiğini bildirmişlerdir. Karaman ve ark. (2020), ikinci ürün olarak yetiştirdikleri maş fasulyesi genotiplerini farklı zamanlarda hasat ettikleri çalışmada genotiplerin ME 10.33-11.10 $\mathrm{MJ} \mathrm{kg}^{-1}$ arasında değişim gösterdiğini ve hasat zamanının gecikmesi ile ME miktarında azalma olduğunu saptamışlardır. Yapılan literatür çalışmaları sonucunda ME değeri yıllara, genotip ve türlere, vejetasyon süresine, bitki kısımlarına ve çevre şartlarına göre değişim göstermektedir. Yapılan çalışmada maş fasulyesinin ME değerleri literatürler ile uyum içerisindedir (Karabulut ve ark., 2007; Karaman ve ark., 2020).

Tablo 4. Maş fasulyesi genotip ve çeşitlerinin bitki kısımlarına göre metabolik enerji içerikleri Table 4. Metabolic energy content of mung bean genotype and varieties according to plant parts

\begin{tabular}{|c|c|c|c|c|}
\hline \multirow{2}{*}{$\begin{array}{c}\text { Genotip/Çeşit } \\
\text { Genotype/Variety }\end{array}$} & \multicolumn{4}{|c|}{ Metabolik Enerji (MJ kg-1)/Metabolic Energy } \\
\hline & Gövde/Stem & Yaprak/Leaf & Bakla kabuğu /Pod husk & Ort./Mean \\
\hline 02 G 05 & $8.77 \mathrm{ij}$ & $10.30 \mathrm{j}$ & $7.50 \mathrm{~d}-\mathrm{h}$ & $8.86 K L$ \\
\hline 07 A 02 & $8.67 \mathrm{j}$ & $11.20 \mathrm{~b}-\mathrm{d}$ & $7.60 \mathrm{c}-\mathrm{e}$ & $9.16 E-I$ \\
\hline 07 A 05 & 9.33 ef & $10.70 \mathrm{~g}-1$ & $7.40 \mathrm{e}-1$ & $9.14 E-I$ \\
\hline 07 G 01 & $9.20 \mathrm{fg}$ & $10.73 \mathrm{~g}-1$ & $7.40 \mathrm{e}-1$ & $9.11 E-J$ \\
\hline 07 G 08 & $8.70 \mathrm{j}$ & $11.00 \mathrm{~d}-\mathrm{f}$ & $7.60 \mathrm{de}$ & $9.10 F-J$ \\
\hline 07 G 09 & $9.07 \mathrm{gh}$ & $10.30 \mathrm{j}$ & $7.60 \mathrm{de}$ & $9.00 \mathrm{I}-\mathrm{K}$ \\
\hline 21 B 01 & $10.27 \mathrm{a}$ & $11.50 \mathrm{a}$ & $7.90 \mathrm{~b}$ & $9.89 \mathrm{~A}$ \\
\hline 27 N 01 & $9.70 \mathrm{c}$ & $11.20 \mathrm{~b}-\mathrm{d}$ & $7.80 \mathrm{bc}$ & $9.57 B$ \\
\hline 27 S 01 & $9.87 \mathrm{bc}$ & $11.20 \mathrm{~b}-\mathrm{d}$ & $7.60 \mathrm{de}$ & $9.56 B$ \\
\hline 27 S 08 & $9.97 \mathrm{~b}$ & $11.30 \mathrm{ab}$ & $8.10 \mathrm{a}$ & $9.79 \mathrm{~A}$ \\
\hline 33 М 02 & $8.80 \mathrm{ij}$ & $10.87 \mathrm{f}-\mathrm{h}$ & $7.50 \mathrm{~d}-\mathrm{g}$ & $9.06 G-K$ \\
\hline 46 G 01 & $9.47 \mathrm{de}$ & $10.87 \mathrm{f}-\mathrm{h}$ & $7.30 \mathrm{~h}-\mathrm{j}$ & $9.21 \mathrm{D}-H$ \\
\hline 50 N 01 & $9.73 \mathrm{c}$ & $11.07 \mathrm{c}-\mathrm{e}$ & $7.33 \mathrm{~g}-1$ & $9.38 B-D$ \\
\hline 60 M 01 & $9.27 \mathrm{fg}$ & $11.03 \mathrm{c}-\mathrm{f}$ & $7.57 \mathrm{~d}-\mathrm{f}$ & $9.29 C-F$ \\
\hline 65 M 01 & $9.23 \mathrm{fg}$ & $10.90 \mathrm{e}-\mathrm{g}$ & $7.20 \mathrm{ij}$ & $9.11 F-J$ \\
\hline $73 \mathrm{~A}$ & 7.971 & $10.67 \mathrm{~h} 1$ & $7.20 \mathrm{ij}$ & $8.61 M$ \\
\hline $73 \mathrm{C}$ & 9.33 ef & $10.90 \mathrm{e}-\mathrm{g}$ & $7.43 \mathrm{e}-\mathrm{h}$ & $9.22 D-G$ \\
\hline 79 М 01 & $8.93 \mathrm{~h} 1$ & $10.77 \mathrm{~g}-1$ & $7.37 \mathrm{f}-1$ & $9.02 \mathrm{H}-\mathrm{K}$ \\
\hline 79 М 02 & $8.37 \mathrm{k}$ & $10.73 \mathrm{~g}-1$ & $7.63 \mathrm{~cd}$ & $8.91 \mathrm{~J}-K$ \\
\hline Jade-AU & 8.97 h1 & $11.50 \mathrm{a}$ & $8.00 \mathrm{ab}$ & $9.49 B C$ \\
\hline Vidiyala & $8.30 \mathrm{k}$ & $10.60_{1}$ & $7.30 \mathrm{~g}-\mathrm{j}$ & 8.73 LM \\
\hline Partow & $9.13 \mathrm{f}-\mathrm{h}$ & $11.23 \mathrm{bc}$ & $7.90 \mathrm{ab}$ & $9.42 B-D$ \\
\hline Kalkınısh & $9.67 \mathrm{~cd}$ & $11.23 \mathrm{bc}$ & $7.10 \mathrm{j}$ & $9.33 C-E$ \\
\hline Ort./Mean & $9.16 \mathrm{~B}$ & $10.95 A$ & $7.54 C$ & \\
\hline
\end{tabular}

\section{Sonuç}

Ülkemizde yaklaşık 19 milyon büyükbaş hayvan varlığına yetecek kadar kaliteli kaba yem bulunmamaktadır. Yaklaşık 56 milyon ton kaliteli kaba yem açığı olup, bu açığın alternatif bir kaba yem kaynağı olarak baklagil ve Buğdaygil artıklarından karşılanması öngörülmektedir. Bu nedenle hasat sonrasında kalan sap ve samanlar hayvan beslenmesinde kullanılmalıdır. Araştırmada hayvan beslenmede önem arz eden NDF, ADF, ADL, selüloz, TSBM, NYD ve ME özellikleri incelenmiştir. Sonuç olarak NDF, ADF, TSBM ve ME özellikleri değerlendirildiğinde 21 B 01 ve 27 S 08 genotipleri, ADL içeriğinde 60 M 01 genotipi, selüloz içeriğinde 73 A ve 65 M 01 ve NYD'de ise $27 \mathrm{~S} 08$ genotipi üstünlük göstermiştir. Genel olarak bitki kısımlarından gövde ve yaprak kısımlarının hayvanların beslemede kullanılabilme potansiyeline sahip olduğu belirlenmiştir. 


\section{Kaynakça}

Abd El-Salam, M.S., El-Habbasha, S.F. (2008). Evaluation of maize-mungbean intercropping systems at different sowing dates for forage production. Egyptian Journal of Agronomy, 30(2), 279-294.

Abd El-Salam, M.S., Ashour, N.I., Abd El-Ghany, H.M. (2008). Forage production in sole and mixed stands of fodder maize (Zea mays L.) and mungbean (Vigna radiata L.Wilczek). Bulletin of the National Research Centre, Egypt, 33(1), 27-34.

Abreu, J. M. F., Bruno-Soares, A. M. (1998). Characterization and utilization of rice, legume and rape straw. Options Mediterraneennes-Serie B, Etudes et Recherches, 17, 39-51.

Acar, Z., Tan, M., Ayan, İ., Aş̧̧ı, Ö. Ö., Mut, H., Başaran, U., Kaymak, G. (2020). Türkiye'de yem bitkileri tarımının durumu ve geliştirme olanakları. Türkiye Ziraat Mühendisliği, 9, 13-12.

Açıkgöz, E. (2001). Yem Bitkileri. Uludağ Üniversitesi Güçlendirme Vakfı, Bursa.

Anjum, M. S., Ahmed, Z. I., Rauf, C. A. (2006). Effect of Rhizobium inoculation and nitrogen fertilizer on yield and yield components of mungbean. International Journal of Agriculture and Biology (Pakistan), 8 (2), 238-240.

Anonymous, 2006. Acid detergent and neutral detergent fiber using ANKOM's fiber analyzer F200. Ankom Technology Corporation, Fairport, NY. http://www.ankom.com/00_products/product_a200.shtml

Anonymous, 2016. Animal feed resources information system, http://www.feedipedia.org/, (Erişim tarihi: 21.01.2021)

Bato, E., Nizam, İ., Tuna, M. (2021). Parlak Brom (Bromus catharticus Vahl.) Hatlarının Ot Verimi ve Bazı Morfolojik Özelliklerinin Belirlenmesi. Journal of Tekirdag Agricultural Faculty, 18(1), 169-178.

Benlioğlu, B., Özkan, U. (2020). Germination and Early Growth Performances of Mung Bean (Vigna radiata (L.) Wilczek) Genotypes Under Salinity Stress. Tekirdăg Ziraat Fakültesi Dergisi, 17(3), 318-328.

Bhardwaj, H. L. (2013). Preliminary evaluation of tepary bean (Phaseolus acutifolius A. gray) as a forage crop. Journal of Agricultural Science, $5(7), 160$.

Boe, A., Twidwell, E. K., Rephart, K. D. (1991). Growth and forage yield of cowpea and mungbean in the Northern Great Plains. Canadian Journal of Plant Science, 71(3), 709-715.

Bruno-Soares, A. M., Abreu, J. M. F., Guedes, C. V. M., Dias-da-Silva, A. A. (2000). Chemical composition, DM and NDF degradation kinetics in rumen of seven legume straws. Animal feed science and technology, 83(1), 75-80.

Budak, F., Budak, F. (2014). Yem bitkilerinde kalite ve yem bitkileri kalitesini etkileyen faktörler. Turkish Journal of Scientific Reviews, 7(1), 01-06.

Canci, H., Toker, C. (2005). The Broad-Sense Heritability for Yield and Yield Components in Mung Bean [Vigna radiata (L.) Wilczek]. GAP IV. Agriculture Congress, 21-23 September, Harran Universitesi, Ziraat Fakültesi, Turkiye, 840-843

El-Salam, M. S. A., El-Metwally, I. M., El-Ghany, H. M. A., Hozayn, M. (2013). Potentiality of using mungbean as a summer legume forage crop under Egyptian condition. Journal of Applied Sciences Research, 9(2), 1238-1243.

Erener, G., Ocak, N., Garipoğlu, A. V., Şahin, A. (2016). Insoluble granite-grit allows broiler chicks to have better growth performance and gut health. Revista Brasileira de Zootecnia, 45(11), 650-654.

Frost, R.A., Wilson, L.M., Launchbaugh, K. L., Hovde, E.M. (2008). Seasonal change in forage value of rangeland weeds in northern 1daho. Invasive Plant Science and Management, 1(4): 343-351

Gökkuş, A. (2011). Türkiye'nin kaba yem üretiminde çayır-mer'a ve yem bitkilerinin yeri ve önemi. Atatürk Üniversitesi Ziraat Fakültesi Dergisi, 25(2) 250-261

Islam, M., Chowdhury, S. A., Alam, M. R. (1997). The effect of supplementation of jackfruit leaves (Artocarpus heterophyllus) and mashkalai (Vigna mungo) bran to common grass on the performance of goats. Asian-Australasian Journal of Animal Sciences, 10(2), 206-209.

Kamalak, A. (2006). Determination of nutritive value of leaves of a native grown shrub, Glycyrrhiza glabra L. using in vitro and in situ measurements. Small Ruminant Research, 64(3), 268-278.

Karabulut, A., Canbolat, O., Kalkan, H., Gurbuzol, F., Sucu, E., Filya, I. (2007). Comparison of in vitro gas production, metabolizable energy, organic matter digestibility and microbial protein production of some legume hays. Asian-Australasian Journal of Animal Sciences, 20(4), $517-522$.

Karaman, R., (2019). Maş Fasulyesi (Vigna radiata Wilczek) Genotiplerinin/Yerel Populasyonlarının Isparta Koşullarında Fenolojik, Morfolojik, Agronomik ve Bazı Teknolojik Özellikler Yönünden Karakterizasyonu. (Doktora Tezi) Isparta Uygulamalı Bilimler Üniversitesi Lisansüstü Eğitim Enstitüsü, Isparta.

Karaman, R., Kaya, M., Türkay, C. (2020). Determination of Forage Yield, Quality and Mineral Content Mung Bean Growing as Second Crop. Turkish Journal of Agriculture-Food Science and Technology, 8(10), 2118-2124.

Mendu, V., Griffiths, J. S., Persson, S., Stork, J., Downie, A. B., Voiniciuc, C., DeBolt, S. (2011). Subfunctionalization of cellulose synthases in seed coat epidermal cells mediates secondary radial wall synthesis and mucilage attachment. Plant Physiology, 157(1), 441-453. 
Meral, N., Çiftçi, C. Y., Ünver, S. (1998). Bakteri Aşılaması ve Değişik Azot Dozlarının Nohut (Cicer arietinum L.)'un Verim ve Verim Öğelerine Etkileri. Tarla Bitkileri Merkez Araştırma Enstitüsü Dergisi, 7(1), 44-59.

Moore, J. E., Undersander, D. J. (2002). Relative forage quality: An alternative to relative feed value and quality index. In Proceedings 13th Annual Florida Ruminant Nutrition Symposium, 32, 16-29.

Nair, R. M., Giri, R. R., Boddepalli, V. N., Prasad, K. V. S. V., Devulapalli, R., Blümmel, M. (2019). Variation in grain yield, fodder quality and animal intake in two dual purpose legume crops: mungbean and vegetable soybean grown in semi-arid tropical India. Legume Research, doi: 10.18805/LR-4078

Nair, R. M., Giri, R. R., Boddepalli, V. N., Sharada, P., Prasad, K. V. S. V., Reddy, Y. R., Blümmel, M. (2015). Variation in mungbean for grain yield, haulm yield and forage quality. Eco-Responsive Feeding and Nutrition Linking Livestock And Livelihood, 32p.

Oktay, G., Temel, S. (2015). Ebu Cehil (Calligonum polygonoides L. ssp. commosum (L’Her.) Çalısının Yıllık Yem Değerinin Belirlenmesi. Gaziosmanpaşa Üniversitesi Ziraat Fakültesi Dergisi, 32(1): 30-36

Omer, H. A., Ahmed, S. M., Abedo, A. A., EL-Nomeary, Y. A., Nasr, S. M., Nassar, S. A. (2018). Incorporation apricot seed kernel as untraditional source of protein in rabbit rations. Bulletin of the National Research Centre, 44(1), 1-9.

Rasby, R. J., Erickson, G. E., Klopfenstein, T., Mark, D. R. (2008). EC08-278 Grazing Crop Residues With Beef Cattle. https://digitalcommons.unl.edu/cgi/viewcontent.cgi?article=5121\&context=extensionhist, (Erişim tarihi: 25.01.2020)

Ravindran, V. (1988). Observations on the forage potential of velvet bean. Journal of the National Science Council of Sri Lanka, 16(2), 175181.

Rohweder, D., Barnes, R. F., Jorgensen, N. (1978). Proposed hay grading standards based on laboratory analyses for evaluating quality. Journal of Animal Science, 47(3), 747-759.

Sherasia, P. L., Garg, M. R., Bhanderi, B. M. (2017). Pulses and their by-products as animal feed. Food and Agriculture Organization of the United Nations (FAO).

Sreerangaraju, G., Krishnamoorthy, U., Kailas, M. M. (2000). Evaluation of Bengal gram (Cicer arietinum) husk as a source of tannin and its interference in rumen and post-rumen nutrient digestion in sheep. Animal Feed Science and Technology, 85(1-2), 131-138.

Ullah, H., Khalil, I. H., Lightfoot, D. A. (2012). Selecting mungbean genotypes for fodder production on the basis of degree of indeterminacy and biomass. Pakistan Journal of Botany, 44(2), 697-703.

Uslu, Ö.S., Akbay, F., Erol, A. (2020). Yemlik Bezelye ve Yemlik Bakla Bitki Kısımlarının Kalite Özellikleri ve Mineral Madde İçeriklerinin Belirlenmesi. Türk Doğa ve Fen Dergisi, 9(1), 118-124.

Van Dyke N.J., Anderson, P.M. (2000). Interpreting a forage analysis. Alabama cooperative extension. Circular ANR890.

Van Soest, P.J. (1994). Fiber and physicochemical properties of feeds in: Nutritional ecology of the ruminant. Second edition. Cornell University press. Ithaca, NY

Van Soest, P. V., Robertson, J. B., Lewis, B. A. (1991). Methods for dietary fiber, neutral detergent fiber, and nonstarch polysaccharides in relation to animal nutrition. Journal of Dairy Science, 74(10), 3583-3597.

Venkateswarlu, S., Srinivas Kumar, D., Raghava Rao, E. (2013). Nutrient utilization in buffalo bulls fed crop residue based rations. Online Journal of Animal and Feed Research, 3(2), 101-105.

Zhai, G., Shen, Y., Zhai, Y., Liu, X., Jiang, H. (2008). Forage yield performance and nutritive value of selected wild soybean ecotypes. Canadian Journal of Plant Science, 88(3), 465-472. 